\title{
ANTIPROLIFERATIVE AND IN SILICO ADMET STUDY OF NEW 4-(PIPERIDIN-1-YLMETHYL)-2- (THIOPHEN-2-YL) QUINOLINE ANALOGUES
}

\section{HARISHKUMAR S, SATYANARAYAN N D*, SANTHOSHA S M}

Department of Pharmaceutical Chemistry, Kuvempu University, Post Graduate Centre, Kadur, Chikkamagaluru - 577 548, Karnataka, India. Email: satya1782005@gmail.com

Received: 06 December 2017, Revised and Accepted: 12 January 2018

\begin{abstract}
Objective: Synthesis and antiproliferative study of novel 4-(piperidin-1-ylmethyl)-2-(thiophen-2-yl) quinoline 7(a-j) derivatives.

Methods: 4-(piperidin-1-ylmethyl)-2-(thiophen-2-yl) quinolines were synthesized by the addition of 4-(chloromethyl)-2-(thiophen-2-yl) quinoline $(0.01 \mathrm{~mol})$, piperidine $(0.01 \mathrm{~mol})$ in DMF (10 v) and $\left.\mathrm{K}_{2} \mathrm{CO}_{3} 0.02 \mathrm{~mol}\right)$. The anticancer activity of the title compounds performed against T-47D, HeLa, HepG2, and MCF-7 human cancer cell lines growth was investigated by MTT assay.
\end{abstract}

Results: The compounds $7 \mathrm{~b}$ and $7 \mathrm{~g}$ exhibited $90 \%$ of the growth inhibitory effect on T-47D, HeLa, and MCF-7 and also $80 \%$ growth inhibition in HepG2 when compared with standard drug paclitaxel.

Conclusion: The synthesized compounds 4-(piperidin-1-ylmethyl)-2-(thiophen-2-yl) quinoline 7(a-j) exhibited a considerable degree of growth inhibition of human cancer cell lines. The synthesized molecules 7 (a-j) are in acceptable range and are less toxic and can be considered as possible hits for drug discovery.

Keywords: MTT assay, In silico, T-47D, HeLa, HepG2, MCF-7, Molinspiration.

(C) 2018 The Authors. Published by Innovare Academic Sciences Pvt Ltd. This is an open access article under the CC BY license (http://creativecommons. org/licenses/by/4. 0/) DOI: http://dx.doi.org/10.22159/ajpcr.2018.v11i4.24147

\section{INTRODUCTION}

Cancer is a disease involving abnormal cell growth, leading to a tumor [1]. In poor countries, cancer kills more people than AIDS, malaria, and tuberculosis combined [2]. Cancer is one of the most serious problems to human life, which has drawn more attention all over the world [3]. Extensive scientific research has been devoted for developing effective anticancer therapeutics, involving an integrated employment of surgical techniques, radiation therapy, and chemotherapy [3]. Heterocyclic compounds are widely distributed in nature. Many are synthesized in laboratories and have been successfully used as clinical agents [4]. Among them, thiophene, a five-membered aromatic sulfurcontaining heterocycle, has proven to be an attractive isostere, resulting in improved effectiveness of a drug [5]. Thiophene core has attracted the attention of the scientific community due to their anticancer and other therapeutic uses [6-18]

On the other hand, quinoline ring derivatives with anticancer potential have also shown excellent results through a different mechanism of action [19]. The anticancer potential of the derivatives on various cancer cells including those of leukemia and other cancer cells of breast, ovary, liver, lung, pancreas, and colon [20].

It is well known that the incorporation of heterocyclic rings into prospective pharmaceutical candidates is a major tactic to gain activity and safety merits [21]. Heterocyclic rings such as thiophene are important pharmacophores in search of molecules with antiproliferation activity [22-27].

In continuation of search on new compounds for antiproliferation treatment from our laboratory [28-32], we discovered that 2-(1-benzofuron-2-yl) quinoline-4-carboxylic acid and its esters [28] and 2-(benzofuran-2-yl)-4-(5-phenyl-4H-1,2,4-triazol-3-yl) quinoline and its derivatives [29] have possessed appreciable cytotoxic properties. Hence, the present work deals with the synthesis and antiproliferative potential of 4-(piperidin-1-ylmethyl)-2-(thiophen-2-yl) quinoline and its derivatives, along with detailed in silico pharmacokinetic and druglikeness properties Scheme 1.

\section{METHODS}

\section{Materials}

Commercially available chemicals are used in the synthesis of compounds $7(\mathrm{a}-\mathrm{j})$. The compounds were purified by column chromatography using silica gel 100-200 mesh with occasional monitoring by pre-coated aluminum thin layer chromatography (TLC) plates procured from Merck. Melting points were recorded by the open capillary method and are uncorrected by Raga Melting Point Apparatus. The ${ }^{1} \mathrm{H}$-nuclear magnetic resonance (NMR) and ${ }^{13} \mathrm{C}$-NMR spectra were recorded on a $400 \mathrm{MHz}$ and $100 \mathrm{MHz}$, Bruker spectrometer using $\mathrm{CDCl}_{3}$ as solvent and TMS as an internal standard. Mass spectra were recorded on the liquid chromatography-mass spectrometry Agilent mass spectrometer.

\section{Method}

2-(1-thiophene-2-yl)quinoline-4-carboxylic acid 3(a-b) Isatin $1(\mathrm{a}-\mathrm{b})(0.01 \mathrm{~mol})$ and ethanol $(10 \mathrm{v})$ were taken in a round bottom flask, to this $33 \%$ aq. $\mathrm{KOH}$ was added dropwise at $0-5^{\circ} \mathrm{C}$ followed by addition of 2 -acetylthiophene $2(0.01 \mathrm{~mol})$. The reaction was refluxed at $75^{\circ} \mathrm{C}$ for $8 \mathrm{~h}$. After completion, the reaction mixture was neutralized with dilute $\mathrm{HCl}$. The precipitate, thus, formed was filtered, washed with ethyl acetate to remove impurities and dried to get compound 3(a-b).

\section{Methyl 2-(1-thiophene-2-yl) quinolone-4-carboxylates 4(a-b)}

2-(1-thiophene-2-yl) quinoline-4-carboxylic acid 3(a-b) (0.01 mol) was taken in methanol (10 v) in a round bottom flask, to this two drops of Conc. $\mathrm{H}_{2} \mathrm{SO}_{4}$ was added. The reaction was refluxed at $75^{\circ} \mathrm{C}$ for $8 \mathrm{~h}$. After completion, the reaction mixture was poured into ice-cold water. The precipitate formed was, thus, filtered and dried to yield 4(a-b). 


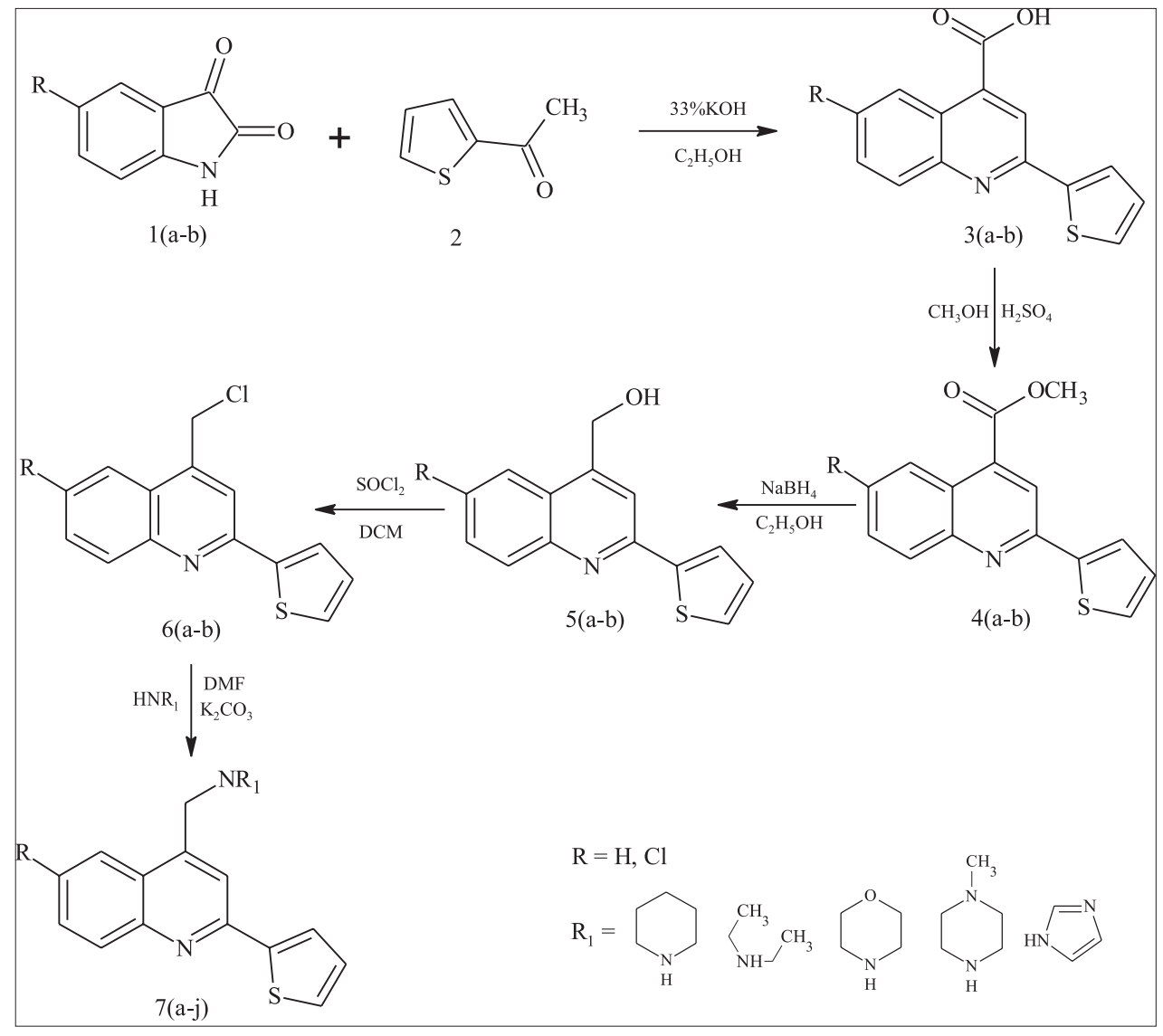

Scheme 1: Synthesis of compounds 7(a-b)

\section{2-(thiophen-2-yl) quinolin-4-yl]methanol 5(a-b)}

Methyl 2-(1-thiophene-2-yl) quinolone-4-carboxylates 4(a-b) $(0.01 \mathrm{~mol})$, methanol $(10 \mathrm{v})$ was taken in a round bottom flask, to this sodium borohydrate $(0.04 \mathrm{~mol})$ was added at $0-5^{\circ} \mathrm{C}$ and kept at ambient temperature for stirring at $25-30^{\circ} \mathrm{C}$ for about $3 \mathrm{~h}$. The progress of the reaction was monitored by TLC. After completion of the reaction, the reaction mixture was poured into ice-cold water; a precipitate formed was filtered and dried to get compounds 5(a-b).

\section{4-(chloromethyl)-2-(thiophen-2-yl) quinoline 6(a-b)}

The compound [2-(thiophen-2-yl)quinolin-4-yl]methanol 5(a-b) $(0.01 \mathrm{~mol})$ was taken in dichloromethane (DCM) $(10 \mathrm{v})$ in a round bottom flask, to this thionyl chloride $(0.04 \mathrm{~mol})$ was added at $0^{\circ} \mathrm{C}$ and kept for stirring at $25-30^{\circ} \mathrm{C}$ for $3 \mathrm{~h}$. After completion of the reaction, the reaction mixture was neutralized with sodium bicarbonate solution and extracted with DCM; the DCM was evaporated to get a solid mass to yield $6(a-b)$.

\section{4-(piperidin-1-ylmethyl)-2-(thiophen-2-yl)quinoline 7(a-j)}

The compound 4-(chloromethyl)-2-(thiophen-2-yl)quinoline 6(a-b) $(0.01 \mathrm{~mol})$ was taken in DMF (10 v) in a round bottom flask, to this $\mathrm{K}_{2} \mathrm{CO}_{3} 0.02 \mathrm{~mol}$ ) was added followed by addition of substituted amine $(0.01 \mathrm{~mol})$. The reaction was kept for stirring at $25-30^{\circ} \mathrm{C}$ for $2 \mathrm{~h}$. The progress of the reaction was monitored by TLC. After the completion of the reaction, the reaction mixture was diluted with water and extracted with ethyl acetate; the organic layer was concentrated and dried. Purification of the synthesized compounds was achieved by column chromatography using n-hexane: Ethyl acetate (v/v) gradient as the mobile phase.

\section{Spectral data}

4-(piperidin-1-ylmethyl)-2-(thiophen-2-yl) quinoline 7(a). Yield (72\%): White amorphous, mp $165-168^{\circ} \mathrm{C}$. Infrared (IR) (KBr) cm ${ }^{-1} 3327$ (Ar C-H),
2922 ( $\mathrm{CH}_{2}$-str), 1647 (C=C), 1295 (C-N), 734 (C-S). ${ }^{1} \mathrm{H}$ NMR (400 MHz, dimethyl sulfoxide [DMSO]- $\mathrm{d}_{6}$ ) (ppm): $1.386(\mathrm{~d}, 2 \mathrm{H}, \mathrm{J}=4.4 \mathrm{~Hz}), 1.478(\mathrm{~d}$, $4 \mathrm{H}, \mathrm{J}=5.6 \mathrm{~Hz}), 2.42(\mathrm{~d}, 4 \mathrm{H}, \mathrm{J}=4.8 \mathrm{~Hz}), 4.384(\mathrm{~s}, 2 \mathrm{H}), 7.202(\mathrm{t}, 1 \mathrm{H}, \mathrm{J}=8.8 \mathrm{~Hz})$, $7.533(\mathrm{t}, 1 \mathrm{H}, \mathrm{J}=1.2 \mathrm{~Hz}), 7.674-7.729(\mathrm{~m}, 2 \mathrm{H}), 7.970-7.971(\mathrm{~m}, 3 \mathrm{H}), 8.223(\mathrm{~d}$, $1 \mathrm{H}, \mathrm{J}=9.2 \mathrm{~Hz}) .{ }^{13} \mathrm{C}$ NMR (100 MHz, DMSO-d $\left.{ }_{6} \mathrm{ppm}\right): 24.149,25.846(2)$, 54.526(2), 59.748, 117.927, 124.941, 126.253, 126.693, 127.166, $128.897,129.083,129.786,130.139,144.981,145.605,147.872,151.691$. Calculated mass: $308.44 \mathrm{~g} / \mathrm{mol}$. MS (ESI-m/z): $309.75(\mathrm{M}+1)$

$N$-ethyl- $N$ - $\{[2$-(thiophen-2-yl)quinolin-4-yl]methyl\}ethanamine $\quad 7$ (b). Yield (70\%): White amorphous, mp 176-180 ${ }^{\circ} \mathrm{C}$. IR (KBr) cm${ }^{-1} 3307$ (Ar C-H), $2922\left(\mathrm{CH}_{2}\right.$-str), 1650 (C=C), 1247 (C-N), 736 (C-S). ${ }^{1} \mathrm{H}$ NMR (400 $\left.\mathrm{MHz}, \mathrm{CDCl}_{3}\right)(\mathrm{ppm}): 1.104(\mathrm{t}, 6 \mathrm{H}, \mathrm{J}=7.2 \mathrm{~Hz}), 2.639(\mathrm{~d}, 4 \mathrm{H}, \mathrm{J}=7.2 \mathrm{~Hz}), 4.048(\mathrm{~s}$, $2 \mathrm{H}), 7.456(\mathrm{t}, 1 \mathrm{H}, \mathrm{J}=1.2 \mathrm{~Hz}), 7.491-7.546(\mathrm{~m}, 3 \mathrm{H}), 7.696(\mathrm{t}, 1 \mathrm{H}, \mathrm{J}=8.4 \mathrm{~Hz})$, $8.025(\mathrm{~s}, 1 \mathrm{H}), 8.183(\mathrm{~d}, 2 \mathrm{H}, \mathrm{J}=8.4 \mathrm{~Hz}), 8.23(\mathrm{~d}, 1 \mathrm{H}, \mathrm{J}=8.4 \mathrm{~Hz}) .{ }^{13} \mathrm{C}$ NMR $(100$ $\left.\mathrm{MHz}, \mathrm{CDCl}_{3} \mathrm{ppm}\right)$ : 11.824(2), 47.465(2), 54.950, 123.635, 125.824, 127.558(2), 128.748(2), 129.134(2), 130.183, 139.924, 146.570, 148.375, 157.031. Calculated mass: $296.42 \mathrm{~g} / \mathrm{mol}$. MS (ESI-m/z): 297.45 (M+1).

4-(morpholin-4-ylmethyl)-2-(thiophen-2-yl)quinoline 7(c). Yield (69\%): White amorphous, $\mathrm{mp} 158-162^{\circ} \mathrm{C}$. IR $(\mathrm{KBr}) \mathrm{cm}^{-1} 3301(\mathrm{Ar}$ C-H), 2922 ( $\mathrm{CH}_{2}$-str), 1649 (C=C), 1245 (C-N), 1012 (C-O), 736 (C-S). ${ }^{1} \mathrm{H}$ NMR (400 MHz, $\mathrm{CDCl}_{3}$ ) (ppm): 1.12(d, $\left.4 \mathrm{H}, \mathrm{J}=7.2 \mathrm{~Hz}\right), 2.638(\mathrm{~d}, 4 \mathrm{H}$, $\mathrm{J}=7.2 \mathrm{~Hz}), 4.001(\mathrm{~s}, 2 \mathrm{H}), 7.466(\mathrm{t}, 1 \mathrm{H}, \mathrm{J}=8.4 \mathrm{~Hz}), 7.528(\mathrm{t}, 2 \mathrm{H}, \mathrm{J}=10 \mathrm{~Hz})$, $7.632(\mathrm{~d}, 1 \mathrm{H}, \mathrm{J}=9.2 \mathrm{~Hz}), 8.033(\mathrm{~s}, 1 \mathrm{H}), 8.105(\mathrm{~d}, 1 \mathrm{H}, \mathrm{J}=9.2 \mathrm{~Hz}), 8.163(\mathrm{~d}$, $1 \mathrm{H}, \mathrm{J}=6.8 \mathrm{~Hz}), 8.252(\mathrm{~d}, 1 \mathrm{H}, \mathrm{J}=2.4 \mathrm{~Hz}) .{ }^{13} \mathrm{C}$ NMR $\left(100 \mathrm{MHz}, \mathrm{CDCl}_{3} \mathrm{ppm}\right):$ 53.123, 56.909(2), 67.950(2), 115.277, 120.058, 120.094, 127.627(2), 128.877(2), 129.904, 148.833, 148.850, 157.260, 157.334, 159.385. Calculated mass: $310.41 \mathrm{~g} / \mathrm{mol}$. MS (ESI-m/z): $311.45(\mathrm{M}+1)$.

4-[(4-methylpiperazin-1-yl)methyl]-2-(thiophen-2-yl)quinoline 7 (d). Yield (68\%): Yellow amorphous, $\mathrm{mp} 180-183^{\circ} \mathrm{C}$. IR (KBr) cm${ }^{-1}: 3354(\mathrm{Ar}$ C-H), 2931 ( $\mathrm{CH}_{2}$-str), $1649(\mathrm{C}=\mathrm{C}), 1297(\mathrm{C}-\mathrm{N}), 762(\mathrm{C}-\mathrm{S}) .{ }^{1} \mathrm{H}$ NMR $(400$ 
$\mathrm{MHz}, \mathrm{CDCl}_{3}$ (ppm): 2.303(s, 3H), 2.483-2.617(m, 8H), 3.984(s, 2H), $7.476(\mathrm{t}, 1 \mathrm{H}, \mathrm{J}=6.4 \mathrm{~Hz}), 7.530(\mathrm{t}, 2 \mathrm{H}, \mathrm{J}=9.2 \mathrm{~Hz}), 7.712(\mathrm{t}, 1 \mathrm{H}, \mathrm{J}=7.2 \mathrm{~Hz})$, 7.914(s, 1H), 8.159-8.193(m, 2H), 8.235(d, 1H, J=8Hz). ${ }^{13} \mathrm{C}$ NMR $(100$ $\left.\mathrm{MHz}, \mathrm{CDCl}_{3} \mathrm{ppm}\right): 43.172,53.872(2), 57.506(2), 60.970,113.587$, $119.663,119.698,119.953,125.636,125.700,127.622(2), 128.857(2)$, 129.635, 156.895, 157.513, 159.552. Calculated mass: $323.45 \mathrm{~g} / \mathrm{mol}$. MS (ESI-m/z): $324.4(\mathrm{M}+1)$.

4-(1H-imidazol-1-ylmethyl)-2-(thiophen-2-yl)quinoline $7(\mathrm{e}) . \quad$ Yield (71\%): Yellow amorphous, mp 205-208 ${ }^{\circ} \mathrm{C}$. IR $(\mathrm{KBr}) \mathrm{cm}^{-1} 3302$ (Ar C-H), $3114\left(\mathrm{CH}_{2}\right.$-str), 1677 (C=C), 1273 (C-N), 768 (C-S). ${ }^{1} \mathrm{H}$ NMR (400 MHz, $\mathrm{CDCl}_{3}$ ) (ppm): 4.936(s, 2H), 7.020(t, $\left.1 \mathrm{H}, \mathrm{J}=2.4 \mathrm{~Hz}\right), 7.233(\mathrm{t}, 1 \mathrm{H}, \mathrm{J}=2 \mathrm{~Hz})$, 7.436-7.515(m, 3H), 7.671(s, $1 \mathrm{H}), 7.718(\mathrm{~d}, 1 \mathrm{H}, \mathrm{J}=9.2 \mathrm{~Hz}), 7.879(\mathrm{~d}, 1 \mathrm{H}$, $\mathrm{J}=2.4 \mathrm{~Hz}), 8.014(\mathrm{~d}, 2 \mathrm{H}, J=8 \mathrm{~Hz}), 8.175(\mathrm{~d}, 1 \mathrm{H}, J=8.8 \mathrm{~Hz}) \cdot{ }^{13} \mathrm{C}$ NMR $(100$ $\mathrm{MHz}, \mathrm{CDCl}_{3} \mathrm{ppm}$ ): 53.964, 125.293(2), 127.061, 127.745(2), 128.301, $128.574,131.718(2), 136.795(2), 143.151(2), 148.091,153.718$, 158.952, 166.663. Calculated mass: $291.37 \mathrm{~g} / \mathrm{mol}$. MS (ESI-m/z): $292.40(\mathrm{M}+1)$

6-chloro-4-(piperidin-1-ylmethyl)-2-(thiophen-2-yl)quinoline $\quad 7(\mathrm{f})$. Yield (73\%): White amorphous, mp $182-185^{\circ} \mathrm{C}$. IR (KBr) $\mathrm{cm}^{-1} 3225$ (Ar C-H), 2927 ( $\mathrm{CH}_{2}$-str), 1641 (C=C), 1249 (C-N), 746 (C-S), 659 (C-Cl). ${ }^{1} \mathrm{H}$ NMR (400 MHz, DMSO-d ${ }_{6}$ ) (ppm): $1.133(\mathrm{t}, 2 \mathrm{H}, \mathrm{J}=8.4 \mathrm{~Hz})$, $1.990(\mathrm{t}, 4 \mathrm{H}, \mathrm{J}=3.2 \mathrm{~Hz}), 2.392(\mathrm{~d}, 4 \mathrm{H}, \mathrm{J}=1.6 \mathrm{~Hz}), 4.01(\mathrm{~s}, 2 \mathrm{H}), 7.117(\mathrm{t}, 1 \mathrm{H}$, $\mathrm{J}=8 \mathrm{~Hz}), 7.259(\mathrm{~d}, 1 \mathrm{H}, \mathrm{J}=8.4 \mathrm{~Hz}), 7.354-7.435(\mathrm{~m}, 1 \mathrm{H}), 7.483-7.682(\mathrm{~m}$, $2 \mathrm{H}), 8.254(\mathrm{~d}, 1 \mathrm{H}, \mathrm{J}=1 \mathrm{~Hz}) .{ }^{13} \mathrm{C}$ NMR $(100 \mathrm{MHz}$, DMSO-d $\mathrm{ppm}): 23.949$, $26.049,54.576,59.948,118.027,125.041,126.353,126.693,127.166$, $128.897,129.083,129.786,130.139,144.981,145.605,148.072$, 152.091. Calculated mass: $342.88 \mathrm{~g} / \mathrm{mol}$. MS (ESI-m/z): 343.85 (M+1).

$N$ - $\{[6$ - chloro-2-(thiophen-2-yl) quinolin-4-yl] methyl $\}-N$ ethylethanamine $7(\mathrm{~g})$. Yield $(78 \%)$ : White amorphous, $\mathrm{mp} 162-164^{\circ} \mathrm{C}$. IR (KBr) cm ${ }^{-1} 3413$ (Ar C-H), 2923 ( $\mathrm{CH}_{2}$-str), 1643 (C=C), 1254 (C-N), 760 (C-S), 669 (C-Cl). ${ }^{1} \mathrm{H}$ NMR (400 MHz, $\mathrm{CDCl}_{3}$ ) (ppm): 1.104(t, 6H, $\mathrm{J}=14.4 \mathrm{~Hz}), 2.439(\mathrm{~d}, 4 \mathrm{H}, \mathrm{J}=7.2 \mathrm{~Hz}), 4.208(\mathrm{~s}, 2 \mathrm{H}), 7.456(\mathrm{t}, 1 \mathrm{H}, \mathrm{J}=14.4 \mathrm{~Hz})$, $7.491-7.546(\mathrm{~m}, 2 \mathrm{H}), 7.696(\mathrm{~s}, 1 \mathrm{H}), 8.025(\mathrm{~s}, 1 \mathrm{H}), 8.183(\mathrm{~d}, 1 \mathrm{H}, \mathrm{J}=8 \mathrm{~Hz})$, 8.231(d, $1 \mathrm{H}, \mathrm{J}=8 \mathrm{~Hz}) \cdot{ }^{13} \mathrm{C}$ NMR $\left(100 \mathrm{MHz}, \mathrm{CDCl}_{3} \mathrm{ppm}\right): 13.824(2)$, $49.465(2), 59.950,123.635,125.824,127.558(2), 128.748(2)$, 129.134(2), 130.183, 139.924, 146.570, 148.375, 157.031. Calculated mass: $330.8 \mathrm{~g} / \mathrm{mol}$. MS (ESI-m/z): $331.8(\mathrm{M}+1)$.

6-chloro-4-(morpholin-4-ylmethyl)-2-(thiophen-2-yl)quinoline 7(h). Yield (86\%): Pale yellow amorphous, mp $155-157^{\circ} \mathrm{C}$. IR (KBr) $\mathrm{cm}^{-1:} 3302$ (Ar C-H), 2927 ( $\mathrm{CH}_{2}$-str), 1634 (C=C), 1240 (C-N), 769 (C-S), $663(\mathrm{C}-\mathrm{Cl}) .{ }^{1} \mathrm{H}$ NMR $\left(400 \mathrm{MHz}, \mathrm{CDCl}_{3}\right)$ d NMR $(400 \mathrm{MHz}, \mathrm{CDClel} J=8 \mathrm{~Hz})$, $2.961(\mathrm{~d}, 4 \mathrm{H}, \mathrm{J}=8.8 \mathrm{~Hz}), 4.000(\mathrm{~s}, 2 \mathrm{H}), 7.466(\mathrm{t}, 1 \mathrm{H}, \mathrm{J}=8.4 \mathrm{~Hz}), 7.528(\mathrm{t}, 2 \mathrm{H}$, $\mathrm{J}=8.4 \mathrm{~Hz}), 7.632(\mathrm{~d}, 1 \mathrm{H}, \mathrm{J}=9.2 \mathrm{~Hz}), 8.033(\mathrm{~s}, 1 \mathrm{H}), 8.105(\mathrm{~d}, 1 \mathrm{H}, \mathrm{J}=9.2 \mathrm{~Hz})$, 8.163(d, $1 \mathrm{H}, \mathrm{J}=6.8 \mathrm{~Hz}),{ }^{13} \mathrm{C}$ NMR $\left(100 \mathrm{MHz}, \mathrm{CDCl}_{3} \mathrm{ppm}\right): 51.909(2)$, $59.923,66.950(2), 115.277,120.058,120.094,127.627(2), 128.877(2)$, $129.904,148.833,148.850,157.260,157.334,159.385$. Calculated mass: $344.85 \mathrm{~g} / \mathrm{mol}$. MS (ESI-m/z): $345.8(\mathrm{M}+1)$

6-chloro-4-[(4-methylpiperazin-1-yl)methyl]-2-(thiophen-2-yl) quinoline $7(\mathrm{i})$. Yield (81\%): Yellow amorphous, $\mathrm{mp} 171-174^{\circ} \mathrm{C}$. IR (KBr) $\mathrm{cm}^{-1:} 3201$ (Ar C-H), 2920 ( $\mathrm{CH}_{2}$-str), 1650 (C=C), 1231 (C-N), 742 (CS), 669 (C-Cl). ${ }^{1} \mathrm{H}$ NMR (400 MHz, $\mathrm{CDCl}_{3}$ ) (ppm): $2.112(\mathrm{~s}, 3 \mathrm{H}), 2.483-$ $2.617(\mathrm{~m}, 8 \mathrm{H}), 4.000(\mathrm{~s}, 2 \mathrm{H}), 7.476(\mathrm{t}, 1 \mathrm{H}, \mathrm{J}=6.4 \mathrm{~Hz}), 7.530(\mathrm{t}, 2 \mathrm{H}, \mathrm{J}=9.2 \mathrm{~Hz})$, $7.712(\mathrm{t}, 1 \mathrm{H}, \mathrm{J}=7.2 \mathrm{~Hz}), 7.914(\mathrm{~s}, 1 \mathrm{H}), 8.159-8.193(\mathrm{~m}, 2 \mathrm{H}), 8.224(\mathrm{~s}, 1 \mathrm{H})$. ${ }^{13} \mathrm{C}$ NMR (100 MHz, CDCl $\mathrm{ppm}$ ): 43.100, 52.072(2), 55.906(2), 59.970, 119.663, 119.698, 119.953, 125.636, 125.700, 127.622(2), 128.857(2), 129.635, 156.895, 157.513, 159.552. Calculated mass: $357.9 \mathrm{~g} / \mathrm{mol}$. MS (ESI-m/z): $358.7(\mathrm{M}+1)$.

6-chloro-4-(1H-imidazol-1-ylmethyl)-2-(thiophen-2-yl)quinoline 7(j). Yield (75\%): Yellow amorphous, mp 195-199 ${ }^{\circ} \mathrm{C}$. IR (KBr) $\mathrm{cm}^{-1} 3194$ (Ar C-H), $2918\left(\mathrm{CH}_{2}\right.$-str), 1660 (C=C), 1282 (C-N), 757 (C-S), 658 (CCl). ${ }^{1} \mathrm{H}$ NMR (400 $\left.\mathrm{MHz}, \mathrm{CDCl}_{3}\right)(\mathrm{ppm}): 4.437(\mathrm{~s}, 2 \mathrm{H}), 7.436-7.515(\mathrm{~m}$, $3 \mathrm{H}), 7.671(\mathrm{~s}, 1 \mathrm{H}), 7.718(\mathrm{dd}, 1 \mathrm{H}, \mathrm{J}=2 \mathrm{~Hz}, 2.4 \mathrm{~Hz}), 7.879(\mathrm{~d}, 2 \mathrm{H}, \mathrm{J}=2.4 \mathrm{~Hz})$, $8.014(\mathrm{~d}, 2 \mathrm{H}, \mathrm{J}=8 \mathrm{~Hz}), 8.175(\mathrm{~d}, 1 \mathrm{H}, \mathrm{J}=8.8 \mathrm{~Hz}) .{ }^{13} \mathrm{C}$ NMR $\left(100 \mathrm{MHz}, \mathrm{CDCl}_{3}\right.$ ppm): 51.864, 125.293(2), 127.061, 127.745(2), 128.301, 128.574, 131.718(2), 136.795(2), 143.151(2), 148.091, 153.718, 158.952, 166.663. Calculated mass: $325.8 \mathrm{~g} / \mathrm{mol}$. MS (ESI-m/z): 326.75 (M+1).

\section{Biological activity}

Absorption, distribution, metabolism, excretion, and toxicity prediction

The molecular descriptors of compounds $7(\mathrm{a}-\mathrm{j})$ are predicted by pharmacokinetic parameters such as ADMET. The evaluation of biologically active molecules and to eliminate the poor once can be known by ADMET/SAR studies [33] wherein the active lead molecule which contains undesirable functional groups can be removed based on Lipinski rule. The molecular descriptors of synthesized compounds $7(a-j)$ are optimized using quantitative structure-activity relationship properties. Aqueous solubility (PlogS), blood-brain barrier penetration (QPlogBB), intestinal absorption (logHIA) [34], hepatotoxicity, and Caco-2 cell permeability (QPPCaco) helps to understand drug metabolism for the synthesized molecules.

\section{Antiproliferative activity by MTT assay}

The synthesized compounds 7(a-j) were screened for their in vitro antiproliferation activity against human cancer cell lines (HeLa, HepG2, MCF-7, and T-47D cell lines) by MTT assay (Table 1). The cell lines were obtained from the National Centre of Cell Sciences, Pune, India, and were cultured at a seeding density of $0.2 \times 106$ in DMEM/RPMI medium supplemented with $100 \mathrm{U} / \mathrm{ml}$ penicillin, $10 \% \mathrm{FBS}$, and $100 \mu \mathrm{g} / \mathrm{l}$ streptomycin, respectively, and maintained in a humidified atmosphere with $5 \% \mathrm{CO}_{2}$ at $37^{\circ} \mathrm{C}$. The samples were dissolved in DMSO and further diluted in cell culture medium. The antiproliferative response of different molecules was assessed by MTT assay [35]. Cells $(10,000)$ were plated in $200 \mu \mathrm{l}$ growth medium in the presence or absence of the molecule $(25,50$, and $100 \mu \mathrm{g} / \mathrm{ml})$ in 96 -well culture plates for $24 \mathrm{~h}$. Then, the culture plates were centrifuged at $2000 \mathrm{rpm}$ for $10 \mathrm{~min}$ at room temperature. About $100 \mu \mathrm{l}$ of the supernatant was discarded, and $20 \mu \mathrm{l}$ of MTT ( $5 \mathrm{mg} / \mathrm{ml}$ in PBS) was added to each well and incubated for $4 \mathrm{~h}$ at $37^{\circ} \mathrm{C}$. The viability of the cells was determined using a spectrophotometer at $570 \mathrm{~nm}$. The (50\%) inhibitory concentration, that is, the concentration of the compound required to inhibit cell growth by $50 \%$, was determined.

\section{RESULTS AND DISCUSSION}

\section{Chemistry}

Synthesized 2-(1-thiophene-2-yl) quinoline-4-carboxylic acid 3(a-b) by reacting substituted isatin $1(\mathrm{a}-\mathrm{b})$ with 2 -acetyl thiophene 2 in the presence of $33 \%$ aqueous $\mathrm{KOH}$ and ethanol under reflux condition. Obtained acid 3(a-b) was further esterified using methanol using the catalytic amount of concentration $\mathrm{H}_{2} \mathrm{SO}_{4}$. The ester $4(\mathrm{a}-\mathrm{b})$ was reduced to alcohol using $\mathrm{NaBH}_{4}$ in the presence of methanol. The obtained alcohols 5 (a-b) was further reacted with $\mathrm{SOCl}_{2}$ to yield 4-(chloromethyl)-2(thiophen-2-yl) quinoline 6(a-b). Nucleophilic substitution at $\mathrm{C} 4$ with secondary amines was achieved in the presence of DMF and $\mathrm{K}_{2} \mathrm{CO}_{3}$ to yield title compounds $7(\mathrm{a}-\mathrm{j})$. The structures of all the newly synthesized compounds were confirmed by ${ }^{1} \mathrm{H}$ NMR, ${ }^{13} \mathrm{C}$ NMR, Fourier-transform IR and mass spectral analysis.

The IR spectra of synthesized compounds $7(\mathrm{a}-\mathrm{j})$ showed absorption band between 3194 and $3413 \mathrm{~cm}^{-1}$ due to the $\mathrm{C}-\mathrm{H}$ aromatic stretching. 2913-2918 $\mathrm{cm}^{-1}$ for $-\mathrm{CH}_{2}$ stretching, $1231-1297 \mathrm{~cm}^{-1}$ for C-N stretching, $736-769 \mathrm{~cm}^{-1}$ for C-S stretching, and $659-669 \mathrm{~cm}^{-1}$ for $\mathrm{C}-\mathrm{Cl}$ stretching of $7 \mathrm{f}, 7 \mathrm{~g}, 7 \mathrm{~h}, 7 \mathrm{i}$, and $7 \mathrm{j}$.

In the ${ }^{1} \mathrm{H}$ NMR, the presence of singlet peak within the range of 3.984$4.936 \mathrm{ppm}$ corresponds to $\mathrm{N}-\mathrm{CH}_{2}$ protons of $7(\mathrm{a}-\mathrm{j})$. The peaks resonated between 7.117 and $8.254 \mathrm{ppm}$ corresponding to the aromatic protons of $7(\mathrm{a}-\mathrm{j})$. The doublet peak appeared between 1.133 and $1.386 \mathrm{ppm}$, the triplet between 1.478 and $1.990 \mathrm{ppm}$ and another doublet peaks between 2.39 and $2.42 \mathrm{ppm}$ corresponds to piperidine protons of $7 \mathrm{a}$ 
Table 1: Characterization data of 4-(piperidin-1-ylmethyl)-2-(thiophen-2-yl) quinoline 7(a-j) derivatives

\begin{tabular}{|c|c|c|c|c|c|}
\hline Entry & Methyl chlorides & $2^{\circ}$ amines & Product & $\%$ of yield & M. Pt. ${ }^{\circ} \mathrm{C}$ \\
\hline $7 a$ & & & & 72 & $165-168$ \\
\hline $7 b$ & & & & 70 & $176-180$ \\
\hline $7 c$ & & & & 69 & $158-162$ \\
\hline $7 d$ & & & & 68 & $180-183$ \\
\hline $7 \mathrm{e}$ & & & & 71 & $205-208$ \\
\hline $7 \mathrm{f}$ & & & & 73 & $182-185$ \\
\hline $7 \mathrm{~g}$ & & & & 78 & $162-164$ \\
\hline $7 \mathrm{~h}$ & & & & 86 & $155-157$ \\
\hline $7 \mathrm{i}$ & & & & 81 & $171-174$ \\
\hline $7 j$ & & & & 75 & 195-199 \\
\hline
\end{tabular}

and 7f. The triplet peaks which appeared at $1.104 \mathrm{ppm}$ and the doublet peaks which appeared within the range of 2.439-2.639 ppm correspond to the $\mathrm{H}_{3} \mathrm{C}-\mathrm{H}_{2} \mathrm{C}-\mathrm{N}-\mathrm{CH}_{2}-\mathrm{CH}_{3}$ protons of $7 \mathrm{~b}$ and $7 \mathrm{~g}$. The ${ }^{1} \mathrm{H}$ NMR spectra of morpholine protons in $7 \mathrm{c}$ and $7 \mathrm{~h}$ shows two doublet peaks at 1.12- 
$1.78 \mathrm{ppm}$ and $2.638-2.961 \mathrm{ppm}$. The singlet peak at 2.112-2.303 ppm corresponds to $\mathrm{N}-\mathrm{CH}_{3}$, whereas multiplet appeared at 2.483-2.617 ppm corresponds to piperazine protons of $7 \mathrm{~d}$ and $7 \mathrm{i}$. The ${ }^{13} \mathrm{C}$ NMR spectra showed a peak ranging between 51.864 and $60.970 \mathrm{ppm}$ corresponds to $\mathrm{CH}_{2}-\mathrm{N}$ carbon of $7(\mathrm{a}-\mathrm{j})$. The peaks appeared at $113.587-166.663 \mathrm{ppm}$ corresponding to aromatic carbons of $7(\mathrm{a}-\mathrm{j})$. The peaks appeared at 23.949-24.149, 26.049-25.816, and 54.526-54.576 ppm corresponding to piperidine carbons of $7 \mathrm{a}$ and $7 \mathrm{f}$. The peaks appeared at 11.824-13.824 and 47.465-49.465 ppm corresponding to the $\mathrm{H}_{3} \mathrm{C}-\mathrm{H}_{2} \mathrm{C}-\mathrm{N}-\mathrm{CH}_{2}-\mathrm{CH}_{3}$ carbons of $7 \mathrm{~b}$ and $7 \mathrm{~g}$. The peaks appeared at 51.909-56.91 and 66.95$67.95 \mathrm{ppm}$ corresponding to the morpholine carbons of $7 \mathrm{c}$ and $7 \mathrm{~h}$. The peaks at 43.100-43.172 ppm corresponding to $-\mathrm{N}-\mathrm{CH}_{3}$ of $7 \mathrm{~d}$ and $7 \mathrm{i}$, and also the peaks at 52.072-53.872 and 57.506-55.506 ppm corresponding to piperazine carbons of $7 \mathrm{~d}$ and $7 \mathrm{i}$. The mass analysis of 7 (a-j) displayed the molecular ion peak conforming their molecular weight (MW).

\section{Pharmacokinetic properties}

Before 10 years ago, about $50 \%$ of potential therapeutic compounds failed in clinical trials or were removed from the market due to unacceptable side effects and poor ADME properties. In fact, it is now far less (about $8 \%$ ) compounds that fail due to poor ADME properties, because of advancement in the science of drug discovery/design. Filtering and optimization of ADME properties in the early stage of the drug discovery are intensively investigated [36]. However, the experimental evaluation of ADME profiles is expensive, and the workload cannot meet the demands of drug screening and lead optimization. In conjunction with high throughput in vitro screening, computational techniques that can filter/predict ADME profiles have become an alternative approach [33]. Hence, using computer-based methods such as ADME and SAR tools the molecular descriptors and drug likeness properties were studied.
The pharmacokinetic properties are represented in Table 2. The coefficient of blood/brain barrier penetration $(\operatorname{logB} / \mathrm{B})$ was computed and access with the central nervous system (CNS). The CNS activity was computed on -2 (inactive) to +2 (active) scales which show all the molecules have displayed within an acceptable range. The interpretation of test compounds with references show that compounds were in acceptable range and hence, can be used to make an oral dosage for better absorption, transport, metabolism, and maintain homeostatic condition. The synthesized molecules $7(a-j)$ showed significant activity with human intestinal absorption and metabolism. It is noticed that the reference molecules enhance the bioavailability properties that lead to less toxic effects against the target protein. The functional groups of compounds such as $\mathrm{F}, \mathrm{Cl}$, and $\mathrm{CH}_{3}$ had enhanced $\log \mathrm{P}$ values and have the greatest retention within human intestine The logPGI (substrate), and non-inhibitors have drug-drug interaction within tissue that transforms xenobiotics of vigorous reduction of drug absorption and released more bile (liver) and urine (kidney). The reference range of -5 (poor) to +1 (good) and substrate inhibitor from 0 to 1 in which the reference and test compounds (7a-j) shows good activity with human intestinal absorption and metabolism. The aqueous solubility of compounds lies with a range of 0 (poor) to 2 (good), showed that all the molecules (7a-j) had good solubility and logPapp, and the overall results predicted that test compounds have good drug-like, lead-like, and fragment-like properties.

Drug likeness score and bioactivity score of entitled compounds Lipinski's rule of five is commonly used by pharmaceutical chemists in drug design and development to predict oral bioavailability of potential lead or drug molecules. According to Lipinski's rule of five, a candidate molecule will likely to be orally active, if: (i) The MW is under 500, (ii) the calculated octanol/water partition coefficient $(\log \mathrm{P})<5$, (iii) there should be

Table 2: ADME and pharmacological parameters prediction for the ligands 4-(piperidin-1-ylmethyl)-2-(thiophen-2-yl) quinoline 7(a-j) using admet SAR toolbox

\begin{tabular}{|c|c|c|c|c|c|c|c|}
\hline Ligand & PlogBBa & $\log \mathrm{HIA}^{\mathrm{c}}$ & PCaco $^{b}$ & logpGI (substrate) ${ }^{d}$ & $\log P G I$ (non-inhibitor)e & $P \log S^{f}$ & logpappg \\
\hline $7 a$ & 0.9739 & 0.9933 & 0.5960 & 0.6022 & 0.7155 & -4.5213 & 1.2429 \\
\hline $7 \mathrm{~b}$ & 0.9766 & 1.0000 & 0.6048 & 0.6105 & 0.7204 & -3.6755 & 1.3600 \\
\hline $7 \mathrm{c}$ & 0.9917 & 1.0000 & 0.5411 & 0.5298 & 0.5275 & -3.0107 & 0.9967 \\
\hline $7 d$ & 0.9823 & 1.0000 & 0.6345 & 0.7945 & 0.5000 & -3.1751 & 1.1469 \\
\hline $7 e$ & 0.9794 & 0.9921 & 0.5614 & 0.5914 & 0.7223 & -3.6995 & 1.2795 \\
\hline $7 \mathrm{f}$ & 0.9859 & 0.9972 & 0.5448 & 0.5567 & 0.7417 & -4.1212 & 0.7263 \\
\hline $7 g$ & 0.9695 & 1.0000 & 0.6181 & 0.5999 & 0.7426 & -4.4258 & 1.2817 \\
\hline $7 \mathrm{i}$ & 0.9745 & 1.0000 & 0.6300 & 0.7901 & 0.5671 & -3.7563 & 0.9495 \\
\hline $7 j$ & 0.9739 & 0.9933 & 0.5960 & 0.6022 & 0.7155 & -4.5213 & 1.2429 \\
\hline Paclitaxel & 0.9748 & 0.9140 & 0.8957 & 0.8345 & 0.5509 & -3.8728 & 0.4145 \\
\hline
\end{tabular}

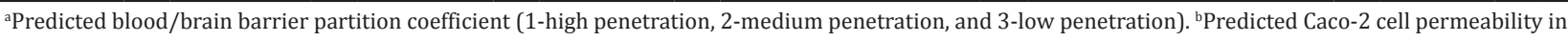

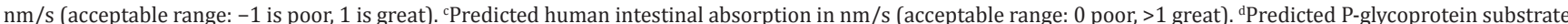
in $\mathrm{nm} / \mathrm{s}$ (acceptable range of -5 is poor, 1 is great). ${ }^{\mathrm{e} P r e d i c t e d ~ P-g l y c o p r o t e i n ~ i n h i b i t o r ~ i n ~} \mathrm{~nm} / \mathrm{s}$ (accepted range: $0-1$ ). ${ }^{\mathrm{f} P r e d i c t e d ~ a q u e o u s ~ s o l u b i l i t y, ~(c o n c e r n ~ v a l u e ~ i s ~} 0-2$

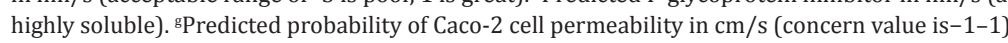

Table 3: Drug likeness score for the synthesized 4-(piperidin-1-ylmethyl)-2-(thiophen-2-yl) quinoline 7(a-j)

\begin{tabular}{|c|c|c|c|c|c|c|c|c|}
\hline Compounds & MW $^{\mathbf{a}}$ & $\operatorname{miLog} \mathrm{P}^{\mathrm{b}}$ & TPSA $^{c}$ & n-Atoms & $n-\mathbf{O N}^{d}$ & n-OHNH ${ }^{e}$ & n-Violation & n-rotb \\
\hline $7 a$ & 308.75 & 4.56 & 16.13 & 22 & 2 & 0 & 0 & 3 \\
\hline $7 \mathrm{~b}$ & 296.44 & 4.40 & 16.13 & 21 & 2 & 0 & 0 & 5 \\
\hline $7 \mathrm{c}$ & 310.42 & 3.50 & 25.36 & 22 & 3 & 0 & 0 & 3 \\
\hline $7 d$ & 323.46 & 3.54 & 19.37 & 23 & 3 & 0 & 0 & 3 \\
\hline $7 \mathrm{e}$ & 291.38 & 3.50 & 30.72 & 21 & 3 & 0 & 0 & 3 \\
\hline $7 \mathrm{f}$ & 342.89 & 5.21 & 16.13 & 23 & 2 & 0 & 1 & 3 \\
\hline $7 \mathrm{~g}$ & 330.88 & 5.06 & 16.13 & 22 & 2 & 0 & 1 & 5 \\
\hline $7 \mathrm{i}$ & 357.91 & 4.20 & 19.37 & 24 & 3 & 0 & 0 & 3 \\
\hline $7 \mathrm{j}$ & 325.82 & 4.15 & 30.72 & 22 & 3 & 0 & 0 & 3 \\
\hline Paclitaxel & 853.92 & 4.95 & 221.31 & 62 & 15 & 4 & 2 & 14 \\
\hline
\end{tabular}

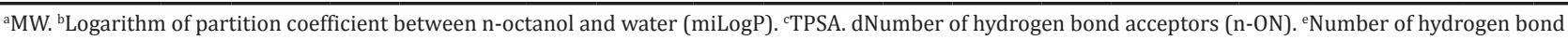
donors (n-OHNH). ${ }^{\mathrm{f}}$ Number of rotatable bonds (n-rotb). MW: Molecular weight, TPSA: Topological polar surface area 
$<5$ hydrogen bond donors ( $\mathrm{OH}$ and $\mathrm{NH}$ groups), and (iv) with $<10$ hydrogen bond acceptors (notably $\mathrm{N}$ and 0 ) [37]. The molecular properties of 4-(piperidin-1-ylmethyl)-2-(thiophen-2-yl) quinoline 7(a-j) derivatives were calculated using molinspiration cheminformatics software and are presented in Table 3. As all the analogs of title compounds obey Lipinski's rule of five, hence, they are considered as orally active.

The bioactivity scores of the title compounds for drug targets were also predicted by molinspiration cheminformatics and are presented in Table 4. A molecule having bioactivity score more than 0.00 is most likely to exhibit considerable biological activities, while values $-0.50-$ 0.00 are expected to be moderately active, and if the score is $<0.50$ it is presumed to be inactive. The results clearly reveal that the physiological actions of synthesized analogs might involve multiple mechanisms of action and could be due to the interactions with G protein-coupled receptors ligands, nuclear receptor ligands, and inhibit protease, and other enzymes. The bioactivity score of compounds is suggestive of significant interaction with all drug targets. The identified compounds showed a better bioactivity score than standard drugs.

\section{Evaluation of antiproliferative activity}

The synthesized compounds $7(\mathrm{a}-\mathrm{j})$ were screened for their in vitro antiproliferative activity against human cancer cell lines, namely, HeLa (human cervical cancer cell line), HepG2 (human liver cancer line), T-47D

Table 4: Bioactive score of the synthesized 4-(piperidin-1-ylmethyl)-2-(thiophen-2-yl) quinoline 7(a-j) according to Molinspiration cheminformatics software

\begin{tabular}{|c|c|c|c|c|c|c|}
\hline Compounds & $\begin{array}{l}\text { GPCR } \\
\text { ligand }\end{array}$ & Ion channel modulator & Kinase inhibitor & Nuclear receptor ligand & Protease inhibitor & Enzyme inhibitor \\
\hline $7 a$ & 0.04 & -0.10 & 0.19 & -0.20 & -0.14 & 0.07 \\
\hline $7 \mathrm{~b}$ & -0.06 & -0.17 & 0.14 & -0.28 & -0.28 & 0.01 \\
\hline $7 c$ & -0.06 & -0.21 & 0.22 & -0.24 & -0.19 & 0.01 \\
\hline $7 d$ & 0.05 & -0.07 & 0.27 & -0.23 & -0.15 & 0.05 \\
\hline $7 \mathrm{e}$ & 0.02 & -0.18 & 0.18 & -0.33 & -0.22 & 0.35 \\
\hline $7 f$ & 0.04 & -0.10 & 0.17 & -0.19 & -0.14 & 0.03 \\
\hline $7 \mathrm{~h}$ & -0.05 & -0.21 & 0.20 & -0.23 & -0.19 & -0.03 \\
\hline $7 \mathrm{i}$ & 0.05 & -0.08 & 0.24 & -0.24 & -0.16 & 0.01 \\
\hline $7 \mathrm{j}$ & 0.03 & -0.18 & 0.18 & -0.30 & -0.21 & 0.30 \\
\hline Paclitaxel & -2.67 & -3.43 & -3.51 & -3.12 & -2.0 & -2.87 \\
\hline
\end{tabular}

GPCR: G protein-coupled receptors

Table 5: Antiproliferative activity of 4-(piperidin-1-ylmethyl)-2-(thiophen-2-yl) quinoline 7(a-j)

\begin{tabular}{|c|c|c|c|c|c|}
\hline \multicolumn{6}{|c|}{ Percentage growth inhibition in different cell lines } \\
\hline Compound & Concentration $(\mu \mathrm{m})$ & Hela & Hepg $_{2}$ & MCF-7 & T-47D \\
\hline \multirow[t]{2}{*}{$7 \mathrm{a}$} & 25 & 20.87721 & 25.73231 & 31.89912 & 21.17284 \\
\hline & 100 & 30.13156 & 29.13386 & 35.72314 & -9.56913 \\
\hline \multirow[t]{3}{*}{$7 \mathrm{~b}$} & 25 & 52.76516 & 45.81726 & 49.77011 & 39.32581 \\
\hline & 50 & 53.18087 & 45.91121 & 46.27713 & 34.15842 \\
\hline & 100 & 52.65265 & 44.41213 & 48.12171 & 33.15023 \\
\hline \multirow[t]{3}{*}{$7 c$} & 25 & 39.33827 & 35.79639 & 34.51121 & -8.13421 \\
\hline & 50 & 39.50112 & 29.68751 & 34.72131 & -3.26211 \\
\hline & 100 & 32.43745 & 32.87938 & 36.31274 & 15.76251 \\
\hline \multirow[t]{3}{*}{$7 d$} & 25 & 41.63125 & 45.12614 & 37.82514 & 28.72461 \\
\hline & 50 & 44.24764 & 38.15654 & 33.12164 & 33.61411 \\
\hline & 100 & 49.12156 & 42.34789 & 35.76156 & 34.78854 \\
\hline \multirow[t]{3}{*}{$7 e$} & 25 & 38.0531 & 36.78161 & 38.39513 & 29.75461 \\
\hline & 50 & 32.20339 & 35.41667 & 30.01181 & 33.89321 \\
\hline & 100 & 34.21043 & 39.68872 & 34.79153 & -2.76356 \\
\hline \multirow{2}{*}{$7 f$} & 50 & 35.61231 & 30.45886 & 29.44325 & 20.17191 \\
\hline & 100 & 38.71241 & 36.10015 & 32.53151 & 19.20234 \\
\hline \multirow[t]{3}{*}{$7 \mathrm{~g}$} & 25 & 56.38132 & 46.68309 & 45.12321 & 35.25131 \\
\hline & 50 & 57.49688 & 47.25964 & 48.73544 & 38.45816 \\
\hline & 100 & 58.91233 & 49.54812 & 49.96324 & 39.12312 \\
\hline \multirow[t]{3}{*}{$7 \mathrm{~h}$} & 25 & 32.11546 & 28.50015 & 31.65865 & 25.97842 \\
\hline & 50 & 39.23467 & 31.52415 & 32.12865 & 20.87126 \\
\hline & 100 & 37.46793 & 30.56913 & 34.58426 & 28.87412 \\
\hline \multirow[t]{3}{*}{$7 \mathrm{i}$} & 25 & 52.98459 & 39.58741 & 36.58142 & 33.58447 \\
\hline & 50 & 48.69455 & 40.98471 & 43.84155 & 31.97584 \\
\hline & 100 & 53.48645 & 44.98845 & 46.54155 & 36.78451 \\
\hline \multirow[t]{3}{*}{$7 \mathrm{j}$} & 25 & 41.66591 & 21.04568 & 31.56327 & 19.54782 \\
\hline & 50 & 39.58452 & 23.54314 & 34.87542 & 21.85641 \\
\hline & 100 & 45.69824 & 25.67215 & 39.58712 & 30.96412 \\
\hline \multirow[t]{3}{*}{ Paclitaxel } & 25 & 59.36544 & 49.64155 & 44.96321 & 35.63211 \\
\hline & 50 & 62.78245 & 55.69784 & 49.21478 & 40.64165 \\
\hline & 100 & 64.36695 & 58.97541 & 53.94595 & 42.68458 \\
\hline
\end{tabular}

Values are expressed as mean $(n=3)$. HeLa-human cervical cancer cell line, HepG2-human liver cancer line, T-47D-human breast ductal carcinoma cell line,

MCF-7-human breast carcinoma cancer cell line 
(human breast ductal carcinoma cell line), and MCF-7 (human breast carcinoma cancer cell line). Paclitaxel is used as reference standard. The antiproliferative activity results were represented in Table 5. The data represent that some of the compounds exhibited good inhibitory activity toward the growth of HeLa, HePG2, MCF-7, and T-47D cell lines.

In particular, compounds $7 \mathrm{~b}, 7 \mathrm{~g}$, and $7 \mathrm{i}$ showed good antiproliferative activities against HeLa, HepG2, and MCF-7 cells also shows moderate antiproliferative activity against T-47D cell line. Furthermore, 7c, 7d, 7e, $7 \mathrm{f}, 7 \mathrm{~h}$, and $7 \mathrm{j}$ showed moderate antiproliferative activity against HeLa and MCF-7 cell lines, and remaining compound 7a showed moderate inhibition of growth of MCF-7 cell lines. Overall, the compounds 7b and $7 \mathrm{~g}$ are exhibited good antiproliferative activity nearer to the standard anticancer drug paclitaxel in Hela, HepG2, and MCF-7 cell lines.

Previously, in our laboratory, the quinoline C-2 coupled furan and benzofuran moieties shows appreciable antiproliferative activity. Likewise, in the present study, the quinoline C-2 coupled thiophene moieties exhibited potent antiproliferative activity. Due to this, the introduction of thiophene at the $2^{\text {nd }}$ position of quinoline enhances the antiproliferative activity. From the results, $7 \mathrm{~b}$ and $7 \mathrm{~g}$ were found as good antiproliferative agents due to the presence of diethylamino functional group at the $4^{\text {th }}$ position of quinoline ring. The diethylamino alkyl chain is a key structure for binding and also increasing the lipophilicity due to this the molecules might be exhibited good antiproliferative activity.

\section{CONCLUSION}

The compounds $7 \mathrm{~b}, 7 \mathrm{~g}$, and $7 \mathrm{i}$ showed good antiproliferative activities against HeLa, HepG2, and MCF-7 cells, show moderate antiproliferative activity against T-47D cell line. Furthermore, 7a, 7c, 7d, 7e, 7f, 7h, and 7j showed moderate antiproliferative activity against HeLa and MCF-7 cell lines. The ADMET studies of title compounds are found to be obeying the ADME properties and are non-toxic. From the above discussion, we conclude that all the molecules are found to be active and obey Lipinski's rules of five and demonstrated good drug-likeness values. Hence, they can be taken as possible hits, which on further modification can reveal compounds with good activity for future development, either as lead molecules or as drugs.

\section{ACKNOWLEDGMENT}

The authors are thankful to the authorities of Kuvempu University, for providing necessary facilities to carry out the present work, and also the authors are thankful to Dr. Manjunatha H, Assistant Professor, Department of PG Studies and Research in Biotechnology, Kuvempu University, for carryout antiproliferation activity. One of the author (Mr. Harishkumar S) is thankful to SC/ST Cell of Kuvempu University, for providing financial support.

\section{CONFLICTS OF INTEREST}

The authors declare that there is no conflict of interest.

\section{AUTHORS CONTRIBUTION}

Dr. N D Satyanarayan, idea generator and direction of the investigation and overall responsible of the work. Mr. Harishkumar S, researcher working for Ph.D. involved in the synthesis, characterization, Mr. Santhosha S M, researcher, involved in spectral characterization and in silico studies.

\section{REFERENCES}

1. Diaz-Cano SJ. Tumor heterogeneity: Mechanisms and bases for a reliable application of molecular marker design. Int $\mathrm{J}$ Mol Sci 2012;13:1951-2011.

2. Asad M, Daniel S, Mauro F. Redefining global health priorities: improving cancer care in developing settings. J Glob Health 2014;4(1):010304

3. Reinberg S. Health Day News. Geneva: WHO; 2008
4. Katritzky AR. Advances in Heterocyclic Chemistry. New York: Academic Press Publishes; 2002.

5. Dalvie DK, Kalgutkar AS, Khojasteh-Bakht SC, Obach RS, O'Donnell JP. Biotransformation reactions of five-membered aromatic heterocyclic rings. Chem Res Toxicol 2002;15:269-99.

6. Elsabee MZ, Ali EA, Mokhtar SM, Eweis M. Synthesis, characterization polymerization and antibacterial properties of novel thiophene substituted acrylamide. React Funct Polym 2011;71:1187-94.

7. Bonini C, Chiummiento L, Bonis MD, Funicello M, Lupattelli P, Suanno G, et al. Synthesis, biological activity and modelling studies of two novel anti HIV PR inhibitors with a thiophene containing hydroxyl ethyl amino core. Tetrahedron 2005;61:6580-9.

8. Ye D, Zhang Y, Wang F, Zheng M, Zhang X, Luo X, et al. Novel thiophene derivatives as PTP1B inhibitors with selectivity and cellular activity. Bioorg Med Chem 2010;18:1773-82.

9. Brandt W, Mologni L, Preu L, Lemcke T, Gambacorti-Passerini C, Kunick $\mathrm{C}$, et al. Inhibitors of the RET tyrosine kinase based on a 2-(alkylsulfanyl)-4-(3-thienyl)nicotinonitrile scaffold. Eur J Med Chem 2010;45:2919-27.

10. Abdel WB, Abdel GH, Ghada EA, Badria FA. Synthesis, antimicrobial, antioxidant, antiinflammatory and analgesic activities of some new 3-(2'-thienyl)pyrazole based heterocycles. Med Chem Res 2012;21:1418-26.

11. Meotti FC, Silva DO, DosSantos AR, Zeni G, Rocha JB, Nogueira CW. Thiophene and furans derivatives: A new class of potential pharmacological agents. Environ Toxicol Pharmacol 2003;15:37-44.

12. Lu X, Wan B, Franzblau SG, You Q. Design, synthesis and antitubercular evaluation of new 2-acylated and 2-alkylated amino-5-(4(benzyloxy)phenyl)thiophene-3-carboxylic acid derivatives. Part 1. Eur J Med Chem 2011;46:3551-63.

13. Amr AE, Sherif MH, Assy MG, Al OM, Ragab I. Antiarrhythmic, serotonin antagonist and antianxiety actvities of novel substituted thiophene derivatives synthesized from 2-amino-4,5,6,7-tetrahydro$\mathrm{N}$-phenylbenzo[b]thiophene -3-carboxamide. Eur J Med Chem 2010;45:5935-42.

14. Gonzalez JL, Stephens CE, Wenzler T, Brun R, Tanious FA, Wilson WD, et al. Synthesis and antiparasitic evaluation of bis-2,5-[4guanidinophenyl]thiophenes. Eur J Med Chem 2007;42:552-7.

15. Romagnoli R, Baraldi PG, Carrion MD, Cara CL, Cruz-Lopez O, Preti D, et al. Design, synthesis, and biological evaluation of thiophene analogues of chalcones. Bioorg Med Chem 2008;16:5367-76.

16. Diana P, Carbone A, Barraja P, Montalbano A, Martorana A, Dattolo G, et al. Synthesis and antitumor properties of 2,5-bis(3'indolyl)thiophenes: Analogues of marine alkaloid nortopsentin. Bioorg Med Chem Lett 2007; 17:2342-6.

17. Gouda MA, Berghot MA, Baz EA, Hamama WS. Synthesis, antitumor and antioxidant evaluation of some new thiazole and thiophene derivatives incorporated coumarin moiety. Med Chem Res 2012;21:1062-70.

18. Scarpelli R, Di Marco A, Ferrigno F, Laufer R, Marcucci I, Muraglia E, et al. Studies of the metabolic stability in cells of 5-(trifluoroacetyl)thiophene-2-carboxamides and identification of more stable class II histone deacetylase (HDAC) inhibitors. Bioorg Med Chem Lett 2008;18:6078-82.

19. Firestone GL, Sundar SN. Anticancer activities of artemisinin and its bioactive derivatives. Expert Rev Mol Med 2009;11:e32.

20. Lu JJ, Meng LH, Cai YJ, Chen Q, Tong LJ, Lin LP, et al. Dihydroartemisinin induces apoptosis in HL-60 leukemia cells dependent of iron and p38 mitogen-activated protein kinase activation but independent of reactive oxygen species. Cancer Biol Ther 2008; 7:1017-23

21. Srivastava V, Negi AS, Kumar JK, Gupta MM, Khanuja SP. Plantbased anticancer molecules: A chemical and biological profile of some important leads. Bioorg Med Chem 2005;13:5892-908.

22. Micale N, Zappalà M, Grasso S. Synthesis and antitumor activity of 1,3-benzodioxole derivatives. Farmaco 2002;57:853-9.

23. Insuasty B, Orozco F, Quiroga J, Abonia R, Nogueras M, Cobo J, et al. Microwave induced synthesis of novel 8,9-dihydro-7H-pyrimido[4,5-b] $[1,4]$ diazepines as potential antitumor agents. Eur J Med Chem 2008;43:1955-62.

24. Leite AC, daSilva KP, de Souza IA, deAraujo JM, Brondani DJ. Synthesis, antitumor and antimicrobial activities of new peptidyl derivatives containing the 1,3-benzodioxole system. Eur J Med Chem 2004;39:1059-65.

25. Al-Obaid AM, Abdel-Hamide SG, El-Kashef HA, Abdel-Aziz AA, 
El-Azab AS, Al-Khamees HA, et al. Substituted quinazolines, part 3. Synthesis, in vitro antitumor activity and molecular modeling study of certain 2-thieno-4(3H)-quinazolinone analogs. Eur J Med Chem 2009;44:2379-91.

26. Basnet A, Thapa P, Karki R, Choi H, Choi JH, Yun M, et al 2,6-dithienyl4-furyl pyridines: Synthesis, topoisomerase I and II inhibition, cytotoxicity, structure-activity relationship, and docking study. Bioorg Med Chem Lett 2010;20:42-7.

27. Barresi V, Condorelli DF, Fortuna CG, Musumarra G, Scire S. In vitro antitumor activities of 2,6-di-[2-(Heteroaryl)vinyl]pyridines and pyridiniums. Bioorg Med Chem 2002;10:2899-904.

28. Anantacharya R, Manjulatha K, Satyanarayana ND, Santoshkumar S, Kaviraj MY. Antiproliferative, DNA cleavage and ADMET study of substituted 2-(1-benzofuran-2-yl)quinoline-4-carboxylic acid and its esters. Cogent Chem 2016;2:1158382.

29. Santoshkumar S, Manjulatha K, Satyanarayan ND, Anantacharya R, Harishkumar S, Harishkumar HN, et al. Antiproliferative, adme and potential in silico g6pdh inhibitory activity of novel 2-(1-benzofuran2-yl)-4-(5-phenyl-4h-1, 2, 4-triazol-3-yl) quinoline derivatives. Int J Pharm Pharm Sci 2016;8:313-9.

30. Manjunatha KS, Satyanarayan ND, Harishkumar S. Antiproliferative and ADMET screening of novel 3-(1H-indol-3-yl)-1,3-diphenylpropan-1 one derivatives. Cogent Chem 2016;2:1172542.

31. Santhosha SM, Satyanarayan ND, Mahadevan KM, Yogesh DB, Menaka T. Synthesis, antiplasmodial and admet studies of 4-methylamino-2-phenylquinoline analogs. Int J Pharm Pharm Sci 2016;8:173-9

32. Soulshekhar SP, Manjulatha K, Satyanarayan ND. Antiproliferative and DNA cleavage activity of various solvent extracts of Acacia farnesiana linn. Pod. Asian J Pharm Clin Res 2017; 10:197-201.

33. Waring MJ, Arrowsmith J, Leach AR, Leeson PD, Mandrell S, Owen RM, et al. An analysis of the attrition of drug candidates from four major pharmaceutical companies. Nat Rev Drug Discov 2015;14:475-86.

34. Feixiong C, Weihua L, Yadi Z, Jie S, Zengrui W, Guixia L. Admetsar: A comprehensive source and free tool for assessment of chemical ADMET properties. J Chem Inf Model 2012;52:3099-105.

35. Mosmann T. Rapid colorimetric assay for cellular growth and survival: Application to proliferation and cytotoxicity assays. J Immun Meth 1983;65:55-63.

36. Lipinski CA, Lombardo F, Dominy BW, Feeney PJ. Experimental and computational approaches to estimate solubility and permeability in drug discovery and development settings. Adv Drug Deliver Rev 2001;46:3-26.

37. Hou T, Wang J. Structure-ADME relationship: Still a long way to go? Expert Opin Drug Metab Toxicol 2008;4:759-70. 